\title{
CZY POJĘCIE BOGA OSOBOWEGO MOŻE BYĆ POJĘCIEM REGIONALNYM?
}

\section{Krótkie objaśnienie tematu}

Temat* sformułowałem nieco prowokacyjnie. Dla uniknięcia nieporozumień chciałbym więc na wstępie wyjaśnić, jak rozumiem postawione pytanie. Zaznaczam od razu, że pytam o po jęci e 'Boga osobowego' takie, jakim się potocznie posługujemy, ze wszystkimi jego ograniczeniami - i że sugerując jego regionalny charakter mam oczywiście na myśli również jedynie ograniczenia pojęcia i specyficznego dla niego sposobu pojmowania, a nie prawdy, którą ono usiłuje pojąć.

Chciałbym zacząć od zwrócenia uwagi na nieco zaskakujące konsekwencje pewnej potocznej opinii dotyczącej historyczno-kulturowej specyfiki pojęcia osoby i osobowego Boga. Otóż można się spotkać z dość powszechnym przekonaniem, że rozwinięta postać tego pojęcia i stojącego za nim doświadczenia jest szczególnym i wybitnym dobrem kultur wyrosłych w spotkaniu z objawieniem biblijnym i że brak jej w wielkich kulturach dalekowschodnich. Nie mam zamiaru zastanawiać się nad tym, czy jest to opinia poprawna. Sam fakt bowiem, że opinia taka się pojawia, niezależnie od tego, czy jest ona słuszna czy nie, wskazuje na regionalny charakter pojęć. których dotyczy, i wobec tego stanowi wezwanie do dalszej nad nimi refleksji. Jeśli mianowicie opinia o braku tych pojęć w wielkich kulturach Dalekiego Wschodu jest słuszna, należy postawić pytanie o przyczynę tego braku (nie jest nią z pewnością niedostateczna głębia i subtelność refleksji antropologicznej tych kultur) oraz o możliwość spotkania z nimi mimo tego braku na gruncie wartości reprezentowanych przez chrześcijański personalizm. Jeżeli natomiast wspomniana opinia jest nieporozumieniem i wartości reprezentowane przez pojęcie osoby i osobowego Absolutu są żywe także w (tylko pozornie wtedy) apersonalistycznych kulturach Azji, należy postawić pytanie, dlaczego ich tam nie zauważamy, albo raczej:

* Tekst referatu wygłoszonego podczas sympozjum $Z$ problematyki wspótczesnej filozofii religii, 17 XI 1988, w Papieskiej Akademii Teologicznej w Krakowie. 
w jaki sposób są one reprezentowane we własnym i właściwym doświadczeniu kultur, o które chodzi, i w ich refleksji. Nie są to pytania obojętne. Nie są to też z pewnością pytania łatwe. Odpowiedź na nie może bardzo głęboko przekształcić nasz sposób pojmowania osoby, także osobowego Boga. Nie możemy jednak nie pytać, czy i jak możliwe jest pokonanie problemów płynących z wielości i różnorodności przeżyć, doświadczeń i rozeznań, ludzi, kultur i systemów, które należałoby uwzględnić, żeby nasze rozumienie religii, a w szczegóIności jej ostatecznego odniesienia, uwolnić od grożącego mu stale partykularyzmu. Pytanie takie może być punktem wyjścia dyskusji o przyszłości filozofii w ogóle, a dokładniej o tym, czy i pod jakimi warunkami filozofia wypracowana w kulturze zachodniej będzie zdolna zrozumieć zjawiska spoza własnego kręgu kulturowego według ich wewnętrznej intencji, a nie tylko je interpretować według swoich własnych modeli myślowych i pojęć; inaczej mówiąc: czy nasza filozofia i związana $\mathrm{z}$ nią nauka będzie zdolna rzeczywiście wyjść poza krąg kulturowy, z którego się wywodzi?

Teraz kilka słów o tym, co mam na myśli mówiąc w tym kontekście o „pojęciu regionalnym". O regionalnym charakterze pojęć możemy mówić zarówno w sensie czysto teoretycznym (a więc np. ze względu na ścisłą koordynację noezis/noema i związaną z nią konstytucję fenomenologii regionalnych, w ramach których następnie pojawiają się interesujące nas pojęcia) jak i w sensie bardziej potocznym (uwarunkowanie doświadczeń i wywodzących się z nich rozeznań i pojęć przez specyfikę regionu historyczno-kulturowego, w którym się pojawiają). Wydaje się, że w przypadku pojęcia 'osoba' i konsekwentnie pojęcia 'Bóg osobowy' w tradycyjnej myśli zachodniej mamy do czynienia z połączeniem obu rodzajów regionalizmu: specyfikę regionu fenomenologicznego w sensie ścisłym, a więc obszaru rozpoznawanych zjawisk i ich związków (osoba - relacja — dialog — czyn — odpowiedzialność) określa specyfika regionu historyczno-kulturowego, do którego należy ten, który o nie pyta (inspirowany wprost lub pośrednio objawieniem biblijnym). To szczególne połączenie obu postaci regionalizmu stało się jednym ze źródeł zarówno osiągniętej w naszym kręgu kulturowym precyzji, wartości poznawczej i kulturotwórczej siły interesujących nas pojęć jak też ich istotnych ograniczeń i słabości - przede wszystkim szeregu aporii dotyczących odniesień osobowo pojmowanego Absolutu do wszystkiego, co istnieje poza nim.

Oczywiście, od krótkiej refleksji, którą tu proponuję, nie można oczekiwać niczego więcej, jak tylko próby dokładniejszego postawienia kilku podstawowych pytań wiążących się z naszym problemem. Sądzę jednak, że świadomość istnienia tego rodzaju pytań jest dostatecznie ważna, by sprawa była godna chwili uwagi. 
Pytanie pierwsze: problem jedności i statości przedmiotu doświadczenia religijnego

Istotnym, chociaż zazwyczaj nie wypowiadanym głośno i wyraźnie, założeniem prób definicji i typologii religii jest przekonanie o przynajmniej względnej jedności i stałości ostatecznego przedmiotu tego wewnętrznego i zewnętrznego odniesienia człowieka do pewnej pod każdym względem przerastającej go rzeczywistości, którym wydaje się być religia. Przedmiot ten może (a według przekonania wielu musi) pozostać nieokreślony - możemy wiedzieć co najwyżej, że taki przedmiot jest, nie zaś czym on jest. Przekonanie o jedności i stałości ostatecznego przedmiotu doświadczeń religijnych może wobec tego być tylko przekonaniem, a nie owocem sprawdzalnej (pozytywnej) wiedzy w tym drugim przypadku musiałoby bowiem być możliwe osobne, kategorialne określenie tego przedmiotu, tymczasem doświadczenie niemożliwości takiego określenia stanowi jedno - jeśli nie jedyne - wspólne doświadczenie skądinąd zdecydowanie różnych filozoficzno-religijnych objaśnień świata. Niemniej jednak cały wysiłek jednoznacznego porządkowania naszej wiedzy o religiach wydaje się bezsensowny, gdybyśmy nie zakładali, że tym, co w nich wielopostaciowe i zmienne, są historyczne kształty, w jakich dochodzą do głosu ich doświadczenia, natomiast to, co stanowi o ich istocie, pozostaje jedno i niezmienne. Podkreślmy, że chodzi tu o względną jedność i stałość przejawiającą się odmiennie na kolejnych poziomach poznania i refleksji. Takim względnie jednym i stałym przedmiotem doświadczenia religijnego może bowiem być np. generalnie „inny świat” czy też „świat bogów” (a więc poznawany zazwyczaj za pomocą języka symbolicznego pierwszego stopnia przedmiot kolektywny, w stosunku do świata ludzkiego zazwyczaj, chociaż nie bezwzględnie, nadrzędny), albo też (na drugim, bardziej ogólnym stopniu języka symbolicznego) świętość czy tajemnica, która manifestuje się w wielości i różnorodności — to jest w zmienności — poszczególnych zjawisk religijnych. Może też nim być ujmowany w miarę ściśle pojęciowo ostateczny i bezwzględny kres czy podstawa całej doświadczanej przez człowieka rzeczywistości (Absolut, Absolut osobowy).

Trudność, o której tu mowa, dotyczy w większym stopniu prób stworzenia filozoficznie podbudowanych (to jest nie tylko empirycznych) typologii religii, niż prób definiowania istoty religijności. Dla większości obiegowych typologii religii historycznych najważniejszym kryterium uporządkowania jest bowiem ujawniające się $w$ poszczególnych zachowaniach religijnych rozumienie (w znaczeniu egzystencjalnym a nie tylko intelektualnym) ich ostatecznego przedmiotu. Dlatego np. mówimy o religiach kosmocentrycznych (skupionych wokół coraz bardziej subtelnego rozumienia przez człowieka tajemnicy świata i własnego w niej miejsca) i teocentrycznych (opartych o samoobjawienie się osobowego Boga i wobec tego skupionych wokół dziejów tego objawienia 
i ewentualnie poświadczających je pism), a w ramach tych dwu wielkich grup o wielu szczegółowych odmianach i konstelacjach obu elementów. Podział ten i tworzone na jego tle bardziej szczegółowe typologie religii przyjmują jako wyjściowe założenie pewne rozróżnienie, które może być usprawiedliwione tylko wiedzą o przedmiocie religijnego doświadczenia. Wiedza ta może jednak być tylko wiedzą religijną przynajmniej w najogólniejszym znaczeniu tego słowa - a więc nie daje się zdobyć poza doświadczeniem tak czy inaczej religijnym. Zarówno pojęcie 'Boga, który się objawia' (Boga osobowego), jak i odniesienie do 'ostatecznej tajemnicy świata', którą należy przeniknąć, może się pojawić jedynie wewnątrz pewnego religijnego układu odniesień, który trzeba jako taki zaakceptować, żeby móc się posługiwać jego doświadczeniem i płynącą stąd wiedzą. Oznacza to, że każda typologia religii i każda wiedza o ostatecznym kresie religijnej relacji jest w istotnym stopniu uzależniona od otwartej lub ukrytej akceptacji takiego układu odniesień, a tym samym jest zawsze wiedzą uwarunkowaną regionalnie i kulturowo, ponieważ oczywiście nie istnieje taki ponadregionalny, uniwersalny układ odniesień, który pozwalałby uwzględniać i interpretować z równym obiektywizmem i krytycyzmem każde faktycznie występujące religijne doświadczenie. To nieuniknione regionalne uwarunkowanie naszej wiedzy możemy jednak i powinniśmy sobie coraz lepiej uświadamiać - po to, żeby w miarę możności unikać związanych z nim złudzeń i nieporozumień.

Na przedstawione wyżej trudności wskazuję oczywiście nie po to, żeby powiedzieć, że wszelkie usiłowania stworzenia w miarę jednoznacznej definicji i typologii religii są bezwartościowe. Chodzi jedynie o zwrócenie uwagi na względną wartość i dość wyraźnie ograniczone skutki poznawcze takich prób. Wypracowywane w ich ramach pojęcia — to jest określenia podmiotu i kształtu, a zwłaszcza przedmiotu relacji religijnej — mogą więc z całą pewnością służyć orientacji w świecie zjawisk religijnych, mogą porządkować nasze wrażenia i wyobrażenia i mogą thumaczyć ich wspólny sens; nie wydaje się jednak, żeby można było na tej płaszczyźnie — to jest w świadomej abstrakcji od wewnętrznej i istotnej zmienności i dynamiki doświadczenia religijnego i przy milczącym założeniu przynajmniej względnej jedności i stałości jego przedmiotu formułować w pełni odpowiedzialne sądy o istocie religii. W każdym razie nie wydaje się to możliwe dzisiaj, kiedy z jednej strony zdajemy sobie coraz wyraźniej sprawę z przekraczającego nasze dotychczasowe wyobrażenia bogactwa świata zjawisk religijnych, a z drugiej strony wiemy, że brak nam środków i możliwości takiego poznania i zrozumienia często bardzo radykalnie odmiennych od naszego religijnych doświadczeń z innych kręgów kulturowych, abyśmy mogli twierdzić, że nasza wiedza o religijności jest czymś więcej niż tylko pewnym poglądem regionalnym. Pojęcia więc i sądy wypracowywane w ramach prób stworzenia definicji i typologii religii mogą nam oddać bardzo cenne przysługi również przez to, że wskażą miejsca najważniejszych trudności i wła- 
ściwe problemy naszej wiedzy o religiach (taką rolę spełnia doskonale klasyczne zachodnie pojęcie Boga osobowego, o którym przede wszystkim mówimy), ale oczekiwanie od nich czegoś więcej wydaje się — przynajmniej w obecnym stanie rzeczy - nieporozumieniem.

Zdaje się, że najważniejszym (i prawie nieuniknionym) źródłem tego rodzaju nieporozumień jest nie zawsze uświadamiane sobie przez nas nakładanie na sposób objaśniania różnych historycznych doświadczeń religijnych własnych przekonań światopoglądowych (np. pojęć chrześcijańskich, albo pochrześcijańskich odmian światopoglądu ludzi kultury zachodniej). Stąd gotowość stosowania bez wyraźniejszych ograniczeń pewnych teologicznych, filozoficznych, psychologicznych czy socjologicznych schematów interpretacji doświadczenia religijnego, których możliwości w tej dziedzinie są z całą pewnością bardziej niż ograniczone.

\section{Pytanie drugie: dialektyka uniwersalnego i regionalnego wymiaru religijnych doświadczeń i pojęć}

Różnice między jedną i drugą z wymienionych wyżej kategorii historycznych doświadczeń religijnych, a więc między religijnymi doświadczeniami teocentrycznymi i religijnymi doświadczeniami kosmocentrycznymi, wydają się wielokrotnie niepokonalne, a ich podstawowe rozeznania wzajemnie w istocie niekomunikowalne. Także ta niekomunikowalność doświadczeń ma charakter bardziej egzystencjalny niż intelektualny czy techniczny — jest więc nie tyle skutkiem braku odpowiedniego wspólnego języka, metody i techniki komunikacji, ile raczej następstwem dokonywanych koniecznie w każdym autentycznym doświadczeniu religijnym egzystencjalnych zamknięć, ustaleń i związań. Te „religijne związania” znajdują wyraz zarówno na bezpośrednim, symbolicznym, czy też rytualnym poziomie języka religijnego („,Ja jestem Bogiem i nie ma innego”, „Nie ma Boga prócz Boga”, „Uciekam się do Buddy, uciekam się do dharmy, uciekam się do samghi"), jak i na kolejnych coraz wyższych poziomach uogólnienia i refleksji.

Jednym $\mathrm{z}$ najistotniejszych w historii doświadczeń religijnych ludzkości tego rodzaju „ustaleń i związań” na wyższym poziomie refleksji jest klasyczna (a w szczególności chrześcijańska) postać pojęcia Boga osobowego. Bóg objawienia żydowsko-chrześcijańskiego nie może nie być Bogiem osobowym, ale to można rozeznać właśnie i tylko w rzeczywistym (religijnym) spotkaniu z objawieniem biblijnym. Czy jednak istnieje podstawa do twierdzenia, że klasyczne zachodnie, antropocentryczne rozumienie istnienia osobowego, rozwinięte dzięki bezpośredniej i pośredniej inspiracji tym właśnie objawieniem, zostało przez odniesienie go do istnienia Bożego i przez rozwijającą się wokół tego odniesienia pogłębioną refleksję uwolnione od swojej regionalnej genezy i kultu- 
rowych uwarunkowań? Rozsądniej będzie przyjąć, że nie. Wprawdzie teologiczne i filozoficzne oczyszczenie tego pojęcia w dziejach myśli chrześcijańskiej prowadzi do przekonania o jego rzeczywistej teoretycznej uniwersalności (tzn. do przekonania, że został przez nie osiągnięty poziom wiedzy obiektywnej, realnej i koniecznej); jednak nawet dość powierzchowna znajomość świata historycznych i współczesnych idei i wierzeń religijnych wystarcza, by stwierdzić, że pojęcie to, im jest w sensie teoretycznym jaśniejsze i czystsze, tym faktycznie mniej uniwersalne i tym trudniej komunikowalne. Proces jego oczyszczania przez refleksję zarówno ściśle religijną jak i filozoficzną nie prowadzi wcale do jego historycznej (faktycznej) uniwersalizacji; prowadzi, jak powiedzieliśmy, co najwyżej do jego uniwersalizacji ideowej i teoretycznej - ta jest jednak z punktu widzenia (egzystencjalnego) rozumienia zjawisk i doświadczeń religijnych dość złudna: z mojego przekonania, że docieram do wiedzy obiektywnej, realnej i koniecznej nie wynika przecież wcale, że wiedza, do której docieram, jest taka również dla kogokolwiek poza tym duchowym środowiskiem, w którym ja moją „obiektywną, realną i konieczną” wiedzę formułuję. Zauważmy, że doświadczenia religijnego stosunku do zbawczej mocy Chrystusa i do zbawczej mocy Amidy na poziomie tzw. prostych wyznawców są jeszcze względnie łatwo komunikowalne - zapewne wskutek ich silnie intuicyjnego charakteru, ale na poziomie powiedzmy św. Tomasza i Nagardżuny już nie, albo tylko z najwyższym trudem. Zarówno zwolennik św. Tomasza jak i adept nauki Nagardżuny będzie przy tym gotów twierdzić, że to właśnie jego interpretacja jest bliższa „prawdziwej natury rzeczy” — i nie istnieją niezależne (to jest pozareligijne) kryteria, które pozwoliłyby rozstrzygnąć, kto z nich, dlaczego i w jakich granicach ma prawo tak twierdzić.

Pytanie trzecie: napięcie między relacjonalnym i absolutnym wymiarem pojęcia Boga osobowego

Jak wiemy, jedną z najtrudniejszych kwestii związanych z obiegowym pojęciem osobowego Absolutu stanowi praktycznie niepokonalna trudność pogodzenia klasycznego pojęcia przeznaczenia i pojęcia Bożej i ludzkiej wolności jako samodzielności. Istotę problemu stanowi uwikłanie tych pojęć w dylemat, którego z ich pomocą nie da się przezwyciężyć: w dylemat przeciwstawienia zależności i niezależności. Cała siła europejskiego myślenia chrześcijańskiego zdaje się leżeć w umiejętności wprzęgnięcia tego dylematu w opis wzajemnych stosunków trzech istotnych dla tego myślenia wielkości: Boga, człowieka i świata. Zarazem jednak myślenie uwikłane w taki dylemat prawie nie jest w stanie wyobrazić sobie, jak człowiek (i świat) mógłby osiągnąć pełnię własnych możliwości - a wśród nich pełną autonomię — inaczej niż za cenę pewnego pomniejszenia Boga, lub przynajmniej — co ostatecznie wychodzi na jedno 
— za cenę pewnej Jego zależności od decyzji człowieka (nieprzewidywalnych nawet dla Boga, jeśli mają to być decyzje zupełnie wolne, jeśli więc rzeczywiście mogłyby być także inne, niż każdorazowo są). Wydaje się bowiem, że nie mogłoby być decyzji (zupełnie) wolnych, gdyby 'zawsze już' przewidywał je i znał, to jest uprzedzał i przygotowywał, doskonały i niezmienny Bóg, w którym każda możliwość jest już nieodołalnie spełniona - albo więc Bóg nie jest bezwzględnie niezmienny, albo człowiek nie jest wolny. Klasyczna metafizy$\mathrm{ka}$, albo raczej związana $\mathrm{z}$ nią teologia, podejmuje godne najwyższego szacunku wysiłki rozwiązania tego dylematu tak, żeby można było zachować zarówno niezbędne pojęcia filozofii Boga (przede wszystkim pojęcia Bożej wszechmocy, wszechwiedzy i niezmienności), jak też ten historyczny dynamizm i tę otwartość Bożego objawienia na dzieje każdego człowieka i urzeczywistniające się w nich ludzkie możliwości, której domaga się wierność przekazowi biblijnemu o Bogu-Osobie (Trójcy Osób). Zdaje się jednak, że najważniejsza przyczyna trudności, z którą mamy tu do czynienia, nie jest wcale teoretyczna przynajmniej w tym sensie, że nie daje się usunąć przez lepsze, dokładniejsze i bardziej konsekwentne definiowanie i stosowanie pojęć. Najważniejszą przyczyną trudności jest bowiem nasza mało uzasadniona pewność siebie i własnych możliwości, która tam, gdzie chodzi o sprawy ostateczne, jest zupełnie nie na miejscu. To ona właśnie prowadzi do takiego formułowania prawdy o bezwzględnej suwerenności Boga wobec człowieka i (przynajmniej względnej) suwerenności człowieka wobec Boga, że skutkiem może być tylko konflikt obu tych suwerenności

Jesteśmy na tyle oswojeni z myślą o takim partnerskim odniesieniu człowieka do Boga i jest ona dla nas tak ważna (przede wszystkim jako oparcie i uzasadnienie ludzkiej osobowej godności), że prawie nie jesteśmy w stanie postawić pytania: kim jest Bóg, który musi się liczyć z'nie' powiedzianym Mu przez Jego własne stworzenie ( $\mathrm{tj} .:$ pozwala swojemu własnemu stworzeniu określać siebie samego); a jeśli pytanie to się pojawia, jego ostrze zostaje zbyt łatwo stępione przez - wypowiadane często bardziej sentymentalnie niż w pełni świadomie — słowa o szacunku Boga dla wolności stworzenia. Kto bowiem uświadomi sobie prawdziwe znaczenie tych słów, nie potrafi ich już powtórzyć - albo przynajmniej nie potrafi powtórzyć ich bez lęku o to, w jakiego Boga wierzy. Nieszczęście polega jednakże na tym, że także ten lęk, podobnie jak pytanie, z którego on się rodzi, jest owocem przekonania, że człowiek jednak mógłby osądzać Boga - że mógłby wiedzieć, kim Bóg powinien być (dla ludzi), żeby nie przestał być Bogiem. Tak więc, ujawnia się tu rzeczywiście kres możliwości tego sposobu myślenia, który koniecznie wiąże ludzką osobową podmiotowość $\mathrm{z}$ wolnością, rozumianą jako możność samodzielnego (niezależnego) określania przez podmiot siebie samego, własnego losu i czegokolwiek poza sobą (to jest także Boga, który może wtedy jedynie przyjąć ludzką wolną decyzję); kres 
możliwości tego myślenia polega na tym, że jest ono zmuszone umieszczać Boga w obszarze tego właśnie 'czegokolwiek' poza ludzkim podmiotem.

Nasze odniesienie do Boga (a w szczególności odniesienie naszej własnej wolności do zupełnej wolności Boga) jest ściśle związane z naszym doświadczeniem czasu — dokładniej: $\mathrm{z}$ doświadczeniem napięcia między zdarzeniami każdorazowej historii tej naszej wolności, takiej, jaką ona jest w naszych oczach tu i teraz, a dziejami Boga i człowieka widzianymi przez samego Boga jako Jego plan, Jego opatrzność i Jego przeznaczenie - jako jedna i ostateczna całość, w której wszystko się wypełnia. Musimy jednakże zauważyć, że napięcie to niewątpliwie istnieje dla nas, ale tak samo niewątpliwie nie istnieje dla Boga. Istnieje dla nas, ponieważ my tylko z najwyższym trudem jesteśmy w stanie oderwać się od własnego punktu widzenia i zobaczyć własną historię z perspektywy innej niż nasza własna. Nie istnieje dla Boga, ponieważ dla Niego każdy możliwy punkt widzenia może być i jest Jego własnym punktem widzenia w dokładnym znaczeniu tego słowa (co jednak nie musi oznaczać Jego aprobaty dla każdego ludzkiego punktu widzenia). To, że Bóg może widzieć i widzi moją własną historię także moimi oczyma, nie może jednak być i nie jest bez znaczenia dla mnie samego. Takie widzenie nie jest jedynie 'własnością Boga jako Boga' - widzenie moimi oczyma nie może się dziać poza mną. Oznacza to, że w moim widzeniu czegokolwiek nigdy nie jestem zupełnie sam (choćbym nawet był przekonany, że jestem). Im bardziej świadomie przeżywam to 'nie sam', tym bliższy jestem prawdy o tym, co widzę, i tym bliższy jestem własnej wolności. Trzeba jednak jasno widzieć i to, że taka świadomość i płynąca z niej postawa nie jest i nie może być owocem naszego własnego wysiłku (choćby dlatego, że wysiłek człowieka, nawet jeśli się zwraca przeciw jego własnym ograniczeniom, nieuchronnie pozostaje próbą potwierdzenia siebie samego i własnych możliwości). Jesteśmy więc wolni nie dlatego, że możemy oglądać wszystkie rzeczy i zdarzenia tak, jak Bóg je widzi naszymi oczyma i swobodnie działać na podstawie takiej wiedzy, ale dlatego, że zarówno sens rzeczy i zdarzeń, wobec których stajemy (a więc to, czym są one dzisiaj dla nas), jak ich ostateczna prawda (to czym są teraz i zawsze dla Boga), rodzi się w naszym czynnym spotkaniu z Nim samym, które dokonuje się w czasie wybranym i określonym ostatecznie przez Niego samego. Inaczej mówiąc: możemy (oczywiście według naszych ograniczonych możliwości) patrzeć, widzieć i poznawać tak jak patrzy, widzi i poznaje Bóg i możemy działać według tego poznania, ale nie wtedy, kiedy my tego chcemy, albo kiedy nam się to wydaje możliwe, tylko wtedy, kiedy Bóg tego chce i czyni to możliwym. Tę Bożą dyspozycję czasu nazywamy tradycyjnie Bożą opatrznością (providentia). Dotyczy ona całego czasu i wszystkich rzeczy, ale ujawnia się najwyraźniej i najpewniej w czasach i rzeczach odnoszących się bezpośrednio do naszego zbawienia, czyli do ostatecznego zwycięstwa w nas tego Bożego punktu widzenia, o którym tu mówimy. 
Sądzę, że nie wolno nam nie postawić pytania, jakiej metafizyki, jakiej antropologii i jakiej teologii filozoficznej domaga się taka wiara.

\section{Podsumowanie}

Zwrócilimy uwagę na trzy niepokojące kwestie:

1. Pytanie o oparcie przekonania o ostatecznej jedności przedmiotu doświadczenia religijnego $\mathrm{w}$ wielości jego odmian.

2. Pytanie o relację między transcendentalnym charakterem niektórych podstawowych pojęć a ich (pierwotnie) zawsze kategorialną konstrukcją -dotyczące szczególnie wyraźnie i dramatycznie pojęcia osobowego Boga, oraz związane z nim ściśle

3. pytanie o stosunek między relacjonalną a absolutną treścią tego ostatniego pojęcia. Zdajemy sobie sprawę z tego, że rozwiązaniem dylematów, na które te pytania wskazują, nie jest ani ucieczka od metafizyki w rozumianą (rzeczywiście albo tylko na pozór) niemetafizycznie „historię Boga z ludźmi”, ani trwanie w zamkniętym kręgu twierdzeń i pojęć, które mogą prowadzić jedynie do wciąż tych samych aporii. Czy jest jakaś inna droga? Nie możemy odpowiedzieć inaczej niż: jest $\mathrm{z}$ pewnością. Każda inna odpowiedź byłaby tym, co Arystoteles nazywa apaideusia.

\section{KANN DER BEGRIFF DES PERSONALEN GOTTES EIN REGIONALBEGRIFF SEIN?}

\section{Zusammenfassung}

Den Ausgangspunkt des Referates bildet eine kurze Kritik der weit verbreiteten populären Meinung, nach welcher der entwickelte Begriff der Person und konsequent auch der Begriff eines personalen Gottes in den asiatischen Hochkulturen (vor allem in der chinesischen Hochkultur) fehlen. Unabhängig davon, ob diese Meinung berechtigt oder unberechtigt ist, weist sie auf den regionalen Charakter der Grundfassung dieser Begriffe in unserem Denken hin. Es geht dabei um einen zweifachen (sowohl den kultur-historischen, als auch den erkenntnis-theoretischen) Regionalismus. Dazu einige Grundfragen zu stellen, ist die Aufgabe dieser Überlegungen.

Der Verfasser stellt und bespricht drei Fragen:

1. Die Frage danach, ob es sich in der Vielfalt der historischen Gestalten der religiösen Erfahrung um einen und denselben „letzten Gegenstand” dieser Erfahrung handeln kann. Facit: dies kann nur vorausgesetzt, aber nicht bewiesen werden, was ernste Folgen für alle Versuche, eine Definition und eine ihr entsprechende Typologie der religiösen Erfahrung zu schaffen, haben muß.

2. Die Frage nach der Dialektik des Universalen und des Regionalen an jeder religiöscn Erfahrung. Genauere Betrachtung des so angezeigten Problemfeldes zeigt, wie und warum die Verständigung zwischen den Menschen unterschiedlicher religiösen Kulturen auf der Ebene ihrer fun- 
damentalen Erfahrungen möglich, aber zugleich auf der Ebene der entsprechenden Grundbegriffe problematisch ist.

3. Die Frage nach der Spannung zwischen der relationalen und der absoluten Dimension des Begriffes des personalen Gottes. Es wird auf die mehr oder weniger offenkundigen Grenzen der Möglichkeiten dieses Begriffes in seiner klassischen Fassung hingewiesen und gezeigt, wie notwendig eine Neubesinnung in der philosophischen Theologie sein kann. 